\title{
Temperature requirements for growth and temperature tolerance of macroalgae endemic to the Antarctic Region
}

\author{
C. Wiencke ${ }^{1}$, I. tom Dieck ${ }^{2}$ \\ ${ }^{1}$ Institute of Polar and Marine Research, Am Handelshafen 12, D-2850 Bremerhaven, Federal Republic of Germany \\ ${ }^{2}$ Biologische Anstalt Helgoland, Notkestraße 31, D-2000 Hamburg 52, Federal Republic of Germany
}

\begin{abstract}
Temperature requirements for growth and upper temperature tolerance were determined in 6 brown algal and 1 red algal species endemic to the Antarctic region. In microthalli of Himantothalius grandifolius, Phaeurus antarcticus, Desmarestia anceps and in a ligulate member of Desmarestia (Desmarestiales) growth was possible from $0{ }^{\circ} \mathrm{C}$ up to between 10 and $15^{\circ} \mathrm{C}$, and maximum survival temperatures were between 13 and $16^{\circ} \mathrm{C}$. Desmarestialean macrothalli grew optimally between 0 and $5^{\circ} \mathrm{C}$ (next temperature tested: $10^{\circ} \mathrm{C}$ ) and exhibited upper survival temperatures of 11 to $13^{\circ} \mathrm{C}$. The upper survival temperature of microthalli of Elachista antarctica (Chordariales) was $18^{\circ} \mathrm{C}$. Ascoseira mirabilis (Ascoseirales) grew 0 up to $10^{\circ} \mathrm{C}$ and survived $11^{\circ} \mathrm{C}$. Palmaria decipiens (Palmariales) grew 0 up to $10^{\circ} \mathrm{C}$ (next temperature tested: $15^{\circ} \mathrm{C}$ ) and maximum survival temperature was 16 to $17^{\circ} \mathrm{C}$. All considered algae are stenotherm cold water species. Their northern distribution is determined by the winter temperature, just low enough $\left[\leq 5(\mathrm{or} 10)^{\circ} \mathrm{C}\right]$, to allow sufficient growth of the most temperaturesensitive stage in the life cycles of the studied species. Temperature tolerance does not limit algal distribution.
\end{abstract}

\section{INTRODUCTION}

Antarctica has been isolated from the other continents since the opening of the Drake Passage in the Oligocene and its waters have been characterized by low temperatures since the Miocene, i.e. for longer periods than the Arctic Seas (Hempel 1987). Hence, conditions for the development of cold water species were much more favourable in the Southern Ocean than in the Arctic Seas. This hypothesis is supported by Ohno (1984), who found optimal growth at $3^{\circ} \mathrm{C}$ for the endemic Antarctic red alga Phyllophora antarctica (Gigartinales) and by Délépine \& Asensi (1976), who found a maximum survival temperature of $13.5^{\circ} \mathrm{C}$ in the subantarctic/cold temperate Durvillaea antarctica (Durvillaeales). Another indication is the high number of endemites accounting for $35 \%$ of the benthic marine algal flora of West Antarctica (Lüning 1985). The fragmentary evidence for this hypothesis is extended in this study by describing the temperature requirements for growth and the temperature tolerance of the different generations of 7 species growing in the Antarctic region.

\section{MATERIAL AND METHODS}

The investigated algae are listed in Table 1. They were isolated as spores on 2 expeditions to King George Island (South Shetland Islands, Antarctica; Clayton \& Wiencke 1986, Wiencke 1988). Unialgal cultures were maintained in the home laboratories using membrane-filtered culture medium (Sartorius Sartobran II, pore size $0.2 \mu \mathrm{m}$; North Sea water), enriched with nutrients (Provasoli, as listed in Stein 1973). Small developmental stages were kept in petri dishes without aeration. Larger algae were cultivated in 1 or 21 beakers and aerated vigorously with membrane-filtered air (Sartorius cellulose nitrate filter, pore size $0.2 \mu \mathrm{m}$ ). The medium was changed weekly to avoid nutrient depletion. For lighting, cool-white fluorescent tubes (Osram L58/W 19) were used. Photon fluence rates were measured with a Licor LI-185B quantameter equipped with a LI-190 B Quantum Sensor (Biggs et al. 1971).

Growth experiments were performed in culture rooms adjusted to temperatures of $0,5,10$ and $15^{\circ} \mathrm{C}$ ( \pm $1{ }^{\circ} \mathrm{C}$ ). Prior to the start of the growth experiments the 
Table 1. Species, location, isolator and date of collection (King George Island is one of the South Shetlands; Fig. 14)

\begin{tabular}{|c|c|c|c|}
\hline Algal species & Location & Isolator & Date \\
\hline $\begin{array}{l}\text { Elachista antarctica Skottsberg } \\
\text { (Chordariales, Phaeophyta) }\end{array}$ & $\begin{array}{l}\text { King George I. } \\
\text { Ardley Bay }\end{array}$ & Wiencke & $27 \operatorname{Jan} 1986$ \\
\hline $\begin{array}{l}\text { Desmarestia anceps Montagne } \\
\text { (Desmarestiales, Phaeophyta) }\end{array}$ & $\begin{array}{l}\text { King George I. } \\
\text { Ardley Bay }\end{array}$ & Wiencke & $28 \operatorname{Jan} 1987$ \\
\hline $\begin{array}{l}\text { Desmarestia sp. }{ }^{a} \\
\text { (Desmarestiales, Phaeophyta) }\end{array}$ & $\begin{array}{l}\text { King George I. } \\
\text { Sea-elephant Bay }\end{array}$ & Wiencke & $26 \operatorname{Jan} 1987$ \\
\hline $\begin{array}{l}\text { Himantothallus grandifolius } \\
\text { (A. et E. S. Gepp) Moe et Silva } \\
\text { (Desmarestiales, Phaeophyta) }\end{array}$ & $\begin{array}{l}\text { King George I. } \\
\text { Ardley Bay }\end{array}$ & Clayton & $26 \operatorname{Jan} 1986$ \\
\hline $\begin{array}{l}\text { Phaeurus antarcticus Skottsberg } \\
\text { (Desmarestiales, Phaeophyta) }\end{array}$ & $\begin{array}{l}\text { King George I. } \\
\text { Ardley Bay }\end{array}$ & Clayton & 04 Feb 1986 \\
\hline $\begin{array}{l}\text { Ascoseira mirabilis Skottsberg } \\
\text { (Ascoseirales, Phaeophyta) }\end{array}$ & $\begin{array}{l}\text { King George I. } \\
\text { Skua Bay }\end{array}$ & Wiencke & $29 \mathrm{Jan} 1987$ \\
\hline $\begin{array}{l}\text { Palmaria decipiens (Reinsch) Ricker } \\
\text { (Palmariales, Rhodophyta) }\end{array}$ & $\begin{array}{l}\text { King George I. } \\
\text { Sea-elephant Bay }\end{array}$ & Wiencke & $28 \operatorname{Jan} 1987$ \\
\hline
\end{tabular}

algae were placed in the experimental temperature and light conditions for adaptation (10 d). Growth rates were measured in 5 to 20 individuals by determination of filament length, sporeling area or fresh weight. Gametophytes of the Desmarestiales were crushed with pestle and mortar, the resulting few celled filaments were allowed to settle on the petri dishes and were then marked. Filament length or filament area was determined on photographs taken at the beginning and end of each experiment. Areas were measured by means of a Haff Planimeter 315E. Growth experiments with microthalli were performed over a period of 1 to $2 \mathrm{wk}$. Growth of macrothalli was followed over a period of $4 \mathrm{wk}$. Care was taken to use similar developmental stages in each experiment. Growth rates were calculated as

$$
\text { specific growth rate }\left(\% \mathrm{~d}^{-1}\right)=\frac{100 \ln \mathrm{N}_{t} \mathrm{~N}_{0}^{-1}}{t}
$$

where $N_{0}=$ initial size or fresh weight; $N_{t}=$ size or fresh weight on Day $t ; t=$ the time interval

Temperature tolerance was determined in 25 to $250 \mathrm{ml}$ glass-bottles containing the test organisms. The medium was changed 2 to 3 times weekly depending on the size of the organisms. The glass-bottles were immersed in temperature-controlled $\left( \pm 0.1^{\circ} \mathrm{C}\right)$ Haake D 8-V water baths for $2 \mathrm{wk}$. Illumination was the same as in the growth experiments (photon fluence rate: $15 \mu \mathrm{mol} \mathrm{m}{ }^{-2} \mathrm{~s}^{-1} ; 18: 6 \mathrm{~h}$ or $12: 12 \mathrm{~h}$ light: dark cycle). It was assumed that an alga could tolerate a specific temperature if growth was resumed during a postculture of $4 \mathrm{wk}$ under favourable temperature and light conditions. Using the same criterion, temperature toler- ance was also determined using an automatic test system described by Lüning et al. (1987).

\section{RESULTS}

The growth rates of members of the order Desmarestiales at temperatures from 0 to $15^{\circ} \mathrm{C}$ in $5^{\circ} \mathrm{C}$ intervals are shown in Figs. 1 to 11 . The curves indicate that growth is only possible at low temperatures from 0 to 10 (or 15$)^{\circ} \mathrm{C}$ and that sporophytes are more susceptible to higher temperatures than gametophytes. The sporophytes grew optimally at temperatures between 0 and $5{ }^{\circ} \mathrm{C}$ (Figs. 3, 6, 9 and 11); in Desmarestia anceps sporophytic growth rates were optimal at $0{ }^{\circ} \mathrm{C}$ (Fig. 9). All other investigated desmarestialean sporophytes showed similar rates at 0 and $5^{\circ} \mathrm{C}$ (Figs. 3, 6 and 11). Microthalli of Phaeurus antarcticus (Figs. 1 and 2), Desmarestia anceps (Figs. 7 and 8 ) and the ligulate Desmarestia sp. (Fig. 10) grew at temperatures between 0 and $10^{\circ} \mathrm{C}$, showing an optimum at 0 to $5^{\circ} \mathrm{C}$. The female gametophyte of Himantothallus grandifolius also grew at $15^{\circ} \mathrm{C}$ (Fig. 5); optimum temperatures for growth were between 0 and $10^{\circ} \mathrm{C}$. As demonstrated in a pilot experiment, the male $H$. grandifolius gametophyte exhibits a similar behaviour. The experiment shown in Fig. 4 with male $H$. grandifolius was performed under different light conditions (18:6 h versus 12:12 h light:dark cycle and a slightly different photon fluence rate), thereby resulting in a different temperature growth pattern compared to the experiment with the female microthallus. It should be added that gametophytes of $D$. anceps (Figs. 7 and 8) and of 

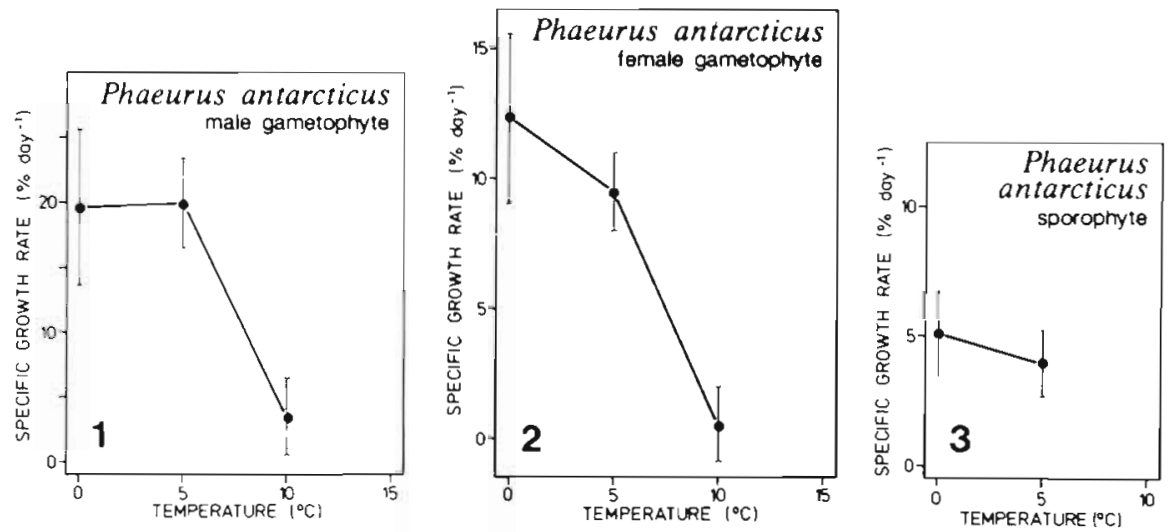

Figs. 1 to 11 . Temperature requirements for growth of Antarctic Desmarestiales. Experiments were performed in $5^{\circ} \mathrm{C}$ intervals. No entries: alga survives the particular temperature but shows no growth. Experiments in Figs. 1, 2, 5 and 10 were performed at $15 \mu \mathrm{mol} \mathrm{m} \mathrm{m}^{-2} \mathrm{~s}^{-1}, 18: 6$ h light:dark cycle; experiments in Figs. 4,7 and 8 were performed at $11 \mu \mathrm{mol} \mathrm{m} \mathrm{m}^{-2} \mathrm{~s}^{-1}, 12: 12 \mathrm{~h}$ light:dark cycle; experiments in Figs. 3, 6, 9 and 11 were performed at $50 \mu \mathrm{mol}$ $\mathrm{m}^{-2} \mathrm{~s}^{-1}, 18: 6 \mathrm{~h}$ light:dark cycle
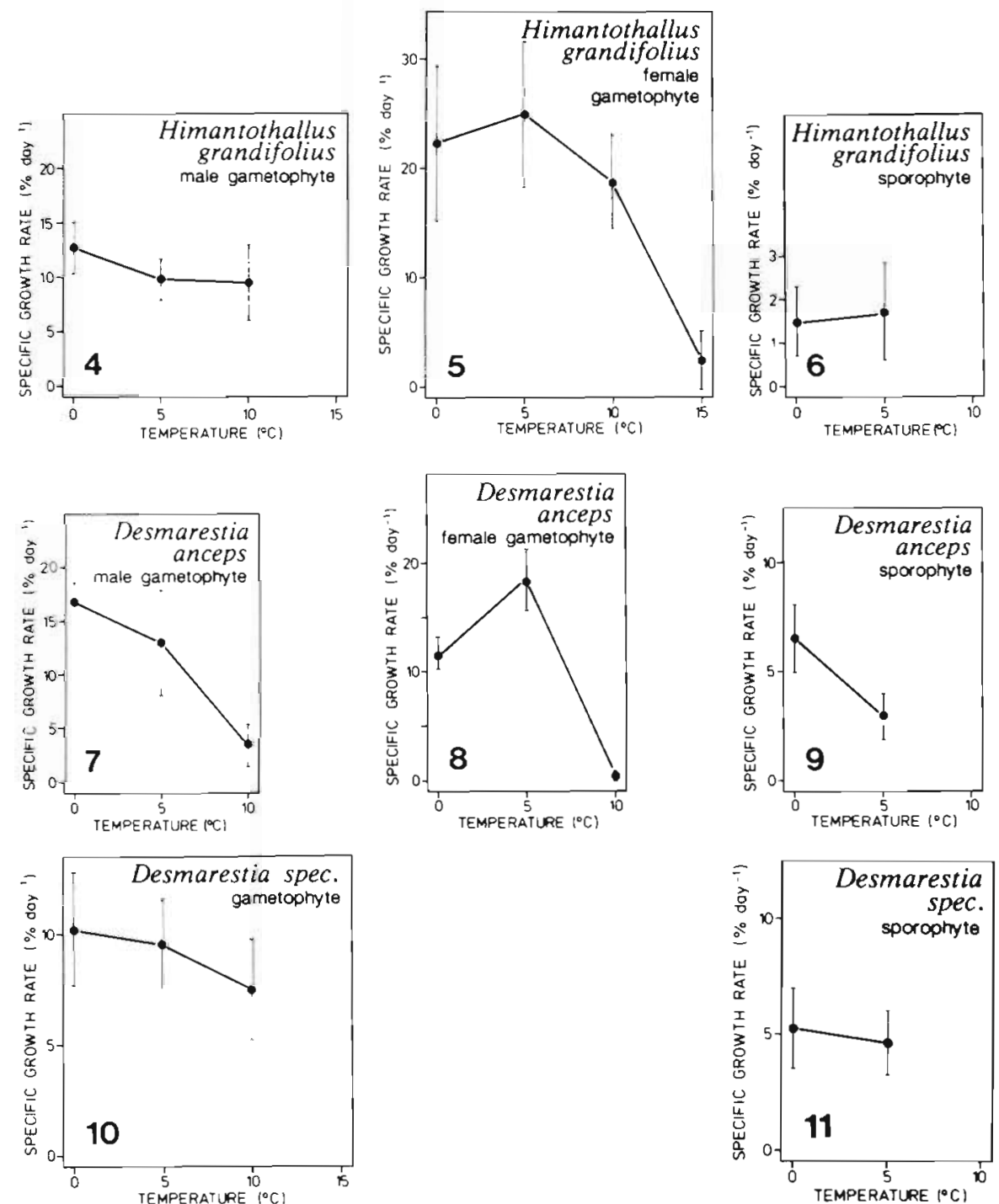

the ligulate Desmarestia sp. (Fig. 10), which were studied under light conditions similar to the experiment with the male $H$. grandifolius (Fig. 4), were unable to grow at $15^{\circ} \mathrm{C}$ even under changed light conditions. This result can also be seen from the maximum survival temperatures of these species (see below). Growth rates of Ascoseira mirabilis and Palmaria decipiens are shown in Figs. 12 and 13. Both algae grew at temperatures between 0 and $10^{\circ} \mathrm{C}$ with an optimum at $5{ }^{\circ} \mathrm{C}$. 

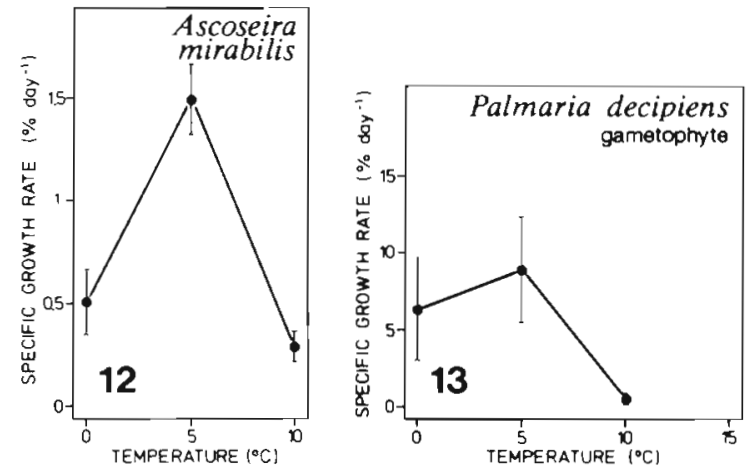

Figs. 12 and 13. Temperature requirements for growth of (Fig. 12) Ascoseira mirabilis (light regime: $25 \mu \mathrm{mol} \mathrm{m} \mathrm{m}^{-2} \mathrm{~s}^{-1}, 18: 6 \mathrm{~h}$ light:dark cycle) and (Fig. 13) Palmaria decipiens (light regime: $50 \mu \mathrm{mol} \mathrm{m} \mathrm{m}^{-2} \mathrm{~s}^{-1}, 18: 6 \mathrm{~h}$ light:dark cycle). Further information in legend of Figs. 1 to 11

Data on upper temperature tolerance are shown in Table 2. The maximum survival temperatures of desmarestialean gametophytes were somewhat higher than those of their sporophytes, similar to the results obtained in the growth experiments. The highest temperatures sustained by the sporophytes were $11^{\circ} \mathrm{C}$ in Phaeurus antarcticus, 11 to $12^{\circ} \mathrm{C}$ in Desmarestia anceps, 11 to $13^{\circ} \mathrm{C}$ in Himantothallus grandifolius and $13^{\circ} \mathrm{C}$ in the ligulate Desmarestia sp. Maximum survival temperatures in the gametophytes of the studied Desmarestiales varied between $13^{\circ} \mathrm{C}$ (male and female D. anceps) to $15^{\circ} \mathrm{C}$ (female $P$. antarcticus) and 15 to $16^{\circ} \mathrm{C}$ (male $P$. antarcticus, male and female $H$. grandifolius). Microthalli of Elachista antarctica survived a temperature of $18^{\circ} \mathrm{C}$, Ascoseira mirabilis survived a temperature of $11^{\circ} \mathrm{C}$ and Palmaria decipiens a temperature of 16 to $17^{\circ} \mathrm{C}$. All specimens studied at higher temperatures than those indicated above did not survive and showed no growth during 4 wk of postcultivation under favourable temperature and light conditions.

\section{DISCUSSION}

The obtained temperature requirements for growth $[\leq 5 \text { to } 10 \text { (or } 15)^{\circ} \mathrm{C}$ with optimum values at 0 to 5 (or 10) ${ }^{\circ} \mathrm{C}$ ) and the maximum survival temperatures (11 to $18^{\circ} \mathrm{C}$ ) of the studied macroalgae correspond well with data of 2 other Antarctic species investigated so far, i.e. Phyllophora antarctica (optimal growth at $3{ }^{\circ} \mathrm{C}$; Ohno 1984) and Durvillaea antarctica (maximum survival temperature: $13.5^{\circ} \mathrm{C}$; Délépine \& Asensi 1976). These low temperature demands for growth and survival of Antarctic species are in contrast to endemic Arctic macroalgae, which exhibit a broader temperature range for growth and show higher maximum survival temperatures - as far as we are aware from the avail- able small number of investigations. For example, the red alga Devaleraea ramentacea isolated in Northern Norway grows best in the range 6 to $10^{\circ} \mathrm{C}$ and growth is possible up to at least $18{ }^{\circ} \mathrm{C}$ (Rueness \& Tanager 1984). The maximum survival temperature of Laminaria solidungula gametophytes from the Canadian Arctic is $18^{\circ} \mathrm{C}$ (Bolton \& Lüning 1982). The temperature demands for growth of cold temperate macroalgae are somewhat higher: sporophytes of Atlantic Laminaria species (L. Saccharina, L. digitata, L. hyperborea) grow at temperatures between 0 and $20^{\circ} \mathrm{C}$, showing an optimum at 10 to $15^{\circ} \mathrm{C}$. Maximum survival temperatures for the gametophytes of these species are 21 to $23^{\circ} \mathrm{C}$ (Bolton \& Lüning 1982) and $20^{\circ} \mathrm{C}$ for the sporophytes (Lüning 1984). Hence, Antarctic macroalgae are stenothermic cold water species, whereas Arctic and cold temperate macroalgae from the Northern hemisphere are relatively more eurythermic. The latter 2 groups differ from each other in their optimum temperatures for growth (below or above $10^{\circ} \mathrm{C}$ ) and in somewhat different upper survival temperatures

The different degrees of adaptation of Arctic and Antarctic species to low temperatures must be seen in conjunction with the fact that the Arctic region is closely linked to the temperate region of the Northern hemisphere, whereas the Antarctic region is isolated from the other continents. Only 5 Arctic endemites are known today and in all cases their distribution extends into the cold temperate region. This contrasts sharply to the high number of endemic Antarctic macroalgae, which account for $35 \%$ of the flora of West Antarctica (Lüning 1985). Moreover, the Arctic has been exposed to low temperatures for a shorter time period compared to the Antarctic region. A cold water history of only 3 million yr as in the Arctic is obviously not sufficient to reduce the temperature demands for growth and survival dramatically. On the other hand a time period of 30 million yr of low water temperatures as in Antarctica may have caused the development of cold water species with a much lower temperature requirement for growth compared to temperate species. A similar process took place in the tropics with respect to the cold tolerance of tropical algae. Their lower temperature tolerance is as high as 5 to $14{ }^{\circ} \mathrm{C}$ as demonstrated by Biebl (1962) in short-term experiments. This high value as compared to temperate species (Biebi 1958) is explained by the fact that the water temperature in tropical regions was never very low and hence, a long time span for the development of species adapted to high water temperatures in the tropics was available as for the development of coldwater species in Antarctica.

The geographic distribution of macroalgae depends on the temperature regime in the respective habitats, allowing the species to grow, to reproduce and to survive (van den Hoek 1982a). Moreover the photo- 
Table 2. Temperature tolerance of the investigated species determined in 2 wk exposures to the given temperatures. $\mathrm{x}$ : specimen alive; $(\mathrm{x}$ ): old parts of the specimen dead, but young parts (buds, meristems) living; -: specimen dead, no growth during 4 wk postculture under favorable conditions. Every developmental stage was tested in 2 to 4 experimental series, indicated in the table on separate lines

\begin{tabular}{|c|c|c|c|c|c|c|c|c|c|c|c|c|c|c|}
\hline $\begin{array}{l}\text { Species, } \\
\text { developmental stage tested }\end{array}$ & $9^{\circ} \mathrm{C}$ & $10^{\circ} \mathrm{C}$ & $11^{\circ} \mathrm{C}$ & $12^{\circ} \mathrm{C}$ & $13^{\circ} \mathrm{C}$ & $14^{\circ} \mathrm{C}$ & $15^{\circ}$ & $16^{\circ}$ & $17^{\circ} \mathrm{C}$ & $18^{\circ} \mathrm{C}$ & $19^{\circ} \mathrm{C}$ & $20^{\circ} \mathrm{C}$ & $21^{\circ} \mathrm{C}$ & $\begin{array}{c}\text { Maximum } \\
\text { survival } \\
\text { temp. }\left({ }^{\circ} \mathrm{C}\right)\end{array}$ \\
\hline \multirow{2}{*}{$\begin{array}{l}\text { Ascoseira mirabilis } \\
1 \text {-yr-old plants }\end{array}$} & $\mathrm{x}$ & $\mathrm{x}$ & $\mathrm{x}$ & - & - & - & & & & & & & & \multirow[t]{2}{*}{11} \\
\hline & $\mathrm{x}$ & $\mathrm{x}$ & $\mathrm{x}$ & - & - & & & & & & & & & \\
\hline \multirow{2}{*}{$\begin{array}{l}\text { Phaeurus antarcticus } \\
\text { Sporophyte, 1-yr-old plants }\end{array}$} & $\mathrm{x}$ & $\mathrm{x}$ & $\mathrm{x}$ & - & - & - & - & - & - & - & - & - & - & \multirow[t]{2}{*}{11} \\
\hline & $x$ & $\mathrm{x}$ & $\mathrm{x}$ & - & - & - & - & - & - & - & - & - & - & \\
\hline \multirow{3}{*}{$\begin{array}{l}\text { Desmarestia anceps } \\
\text { Sporophyte, } 1 / 2 \text {-yr-old plants }\end{array}$} & $\mathrm{x}$ & $\mathrm{x}$ & $\mathrm{x}$ & - & - & - & & & & & & & & \multirow[t]{3}{*}{$11-12$} \\
\hline & & $\mathrm{x}$ & $\mathrm{x}$ & - & - & - & & & & & & & & \\
\hline & & $\mathrm{x}$ & $\mathrm{x}$ & $(\mathrm{x})$ & & & & & & & & & & \\
\hline \multirow{3}{*}{$\begin{array}{l}\text { Himantothallus grandifolius } \\
\text { Sporophyte, 1-yr-old plants }\end{array}$} & & & & & & & & & & & & & & \multirow{5}{*}{$11-13$} \\
\hline & $\mathrm{x}$ & $\mathrm{x}$ & $\mathrm{x}$ & - & - & - & & & & & & & & \\
\hline & & $\mathrm{x}$ & $x$ & - & - & - & - & & & & & & & \\
\hline \multirow[t]{2}{*}{ 1/2-yr-old plants } & & $\mathrm{x}$ & $\mathrm{x}$ & $(x)$ & $(\mathrm{x})$ & - & & & & & & & & \\
\hline & $\mathrm{x}$ & $\mathrm{x}$ & $(\mathrm{x})$ & $(x)$ & (x) & & & & & & & & & \\
\hline \multirow{2}{*}{$\begin{array}{l}\text { Ligulate Desmarestia sp. } \\
\text { Sporophyte }\end{array}$} & & & $x$ & $\mathrm{x}$ & $\mathrm{x}$ & - & & & & & & & & \multirow[t]{2}{*}{13} \\
\hline & & & & & $\mathrm{x}$ & - & - & - & - & & & & & \\
\hline \multirow{2}{*}{$\begin{array}{l}\text { Desmarestia anceps } \\
\text { Male gametophyte }\end{array}$} & $x$ & $x$ & $x$ & $\mathrm{x}$ & $x$ & - & & & & & & & & \multirow[t]{2}{*}{13} \\
\hline & & $x$ & $x$ & & $x$ & - & - & - & - & & & & & \\
\hline \multirow{2}{*}{$\begin{array}{l}\text { Desmarestia anceps } \\
\text { Female gametophyte }\end{array}$} & $x$ & $x$ & $x$ & $x$ & $x$ & - & & & & & & & & \multirow[t]{2}{*}{13} \\
\hline & & $\mathrm{x}$ & $x$ & $x$ & $x$ & - & - & - & - & & & & & \\
\hline \multirow{3}{*}{$\begin{array}{l}\text { Phaeurus antarcticus } \\
\text { Female gametophyte }\end{array}$} & & & & & & & $x$ & - & - & & & & & \multirow[t]{3}{*}{15} \\
\hline & & & & $x$ & $x$ & $x$ & $\mathrm{x}$ & - & & & & & & \\
\hline & & & & & & & $x$ & - & - & - & - & - & - & \\
\hline \multirow{4}{*}{$\begin{array}{l}\text { Phaeurus antarcticus } \\
\text { Male gametophyte }\end{array}$} & & & & & & $\mathrm{x}$ & $\mathrm{x}$ & $x$ & - & & & & & \multirow[t]{4}{*}{$15-16$} \\
\hline & & & & $\mathrm{x}$ & $x$ & $x$ & $x$ & $x$ & - & & & & & \\
\hline & & & & & & & $x$ & $x$ & - & & & & & \\
\hline & & & & & & & $(x)$ & - & - & -- & - & - & - & \\
\hline \multirow{3}{*}{$\begin{array}{l}\text { Himantothallus grandifolius } \\
\text { Male gametophyte }\end{array}$} & & & & & & $x$ & $x$ & $x$ & - & - & - & & & \multirow[t]{3}{*}{$15-16$} \\
\hline & & & & & & $\mathrm{x}$ & $\mathrm{x}$ & - & - & - & & & & \\
\hline & & & & & & $x$ & $x$ & $x$ & - & - & & & & \\
\hline \multirow{3}{*}{$\begin{array}{l}\text { Himantothallus grandifolius } \\
\text { Female gametophyte }\end{array}$} & & & & & & $x$ & $x$ & $x$ & - & - & - & & & \multirow[t]{3}{*}{$15-16$} \\
\hline & & & & & & $x$ & $\mathrm{x}$ & $\mathrm{x}$ & - & - & - & & & \\
\hline & & & & & & $x$ & $x$ & - & - & - & & & & \\
\hline Palmaria decipiens & & & $\mathrm{x}$ & $x$ & $x$ & $x$ & $\mathrm{x}$ & & & & & & & $16-17$ \\
\hline Gametophyte & & & & & & $\mathrm{x}$ & & $\mathrm{x}$ & - & - & & & & \\
\hline & & & & & & $\mathrm{x}$ & $\mathrm{x}$ & $\mathrm{x}$ & $\mathrm{x}$ & & & & & \\
\hline & & & & & & & $\mathrm{x}$ & $x$ & - & & & & & \\
\hline Elachista antarctica & & & & & & & $\mathrm{x}$ & $\mathrm{x}$ & $\mathrm{x}$ & $\mathrm{x}$ & - & - & - & 18 \\
\hline Microthalli & & & & & & & $\mathrm{x}$ & $\mathrm{x}$ & $x$ & $\mathrm{x}$ & - & - & - & \\
\hline
\end{tabular}

period may limit phytogeographic distribution, as the light:dark cycle is responsible for the induction of growth and reproduction in some species (van den Hoek 1982b). Distributions for the studied species are given in Table 3 and Fig. 14, but it must be noted that phytogeographic data are still very scarce and - as discussed below - a number of misidentifications complicate a phytogeographic analysis. Nevertheless, a comparison of the ecophysiological data given in this study with the habitat temperatures (Table 4) reveals that the northern distributions of the investigated species are determined mainly by the algal temperature growth pattern. In the Desmarestiales the temperature growth pattern of the sporophytes rather than that of the gametophytes seems to limit the northern distribution, as their gametophytes still grow at temperatures of 10 to $15^{\circ} \mathrm{C}$ (Figs. 1 to 11 ), a temperature range which none of the species experiences in its habitat. The temperature demands for growth of the sporophytes are lower and correlate with the habitat 
Table 3. Geographic distribution of the investigated species. Sources: Papenfuss (1964), Zaneveld (1966, 1968), Neushul (1968), Simons (1976), Drew (1977), Lamb \& Zimmerman (1977), Seagrief (1984), Anderson (1985), Fletcher (1987), Ricker (1987), Womersley (1987). All locations mentioned except Macquarie Island are within the Antarctic convergence

\begin{tabular}{|ll|}
\hline Algal species & Geographic distribution \\
\hline Elachista antarctica & Antarctic Peninsula \\
Desmarestia anceps & Antarctic Peninsula, South Shetlands, South Orkneys \\
Ligulate Desmarestia sp. recorded under Desmarestia ligulata (Lightfoot) Lamouroux \\
\multicolumn{1}{c|}{ Antarctic entity } & Antarctic Peninsula, South Shetlands, South Orkneys, South Georgia \\
\multicolumn{1}{c}{ Cold-temperate entities } & Tierra del Fuego, Falklands, Crozet, Auckland Islands, Victoria (Australia), South \\
& Africa, Northern hemisphere: cold temperate regions of Atlantic and Pacific Ocean \\
Himantothallus grandifolius & Antarctic Peninsula, Victoria Land, Adelie Coast, Wilkes Land, Queen Mary Coast, \\
& Balleny Islands, South Shetlands, South Orkneys, South Georgia \\
Phaeurus artarcticus & Antarctic Peninsula, South Shetlands \\
Ascoseira mirabilis & Antarctic Peninsula, South Shetlands, South Orkneys, South Georgia \\
Palmaria decipiens & Antarctic Peninsula, Victoria Land, Adelie Coast, Wilkes Land, Queen Mary Coast, Mac \\
& Robertson Coast, Enderby Land, Balleny Islands, South Shetlands, South Orkneys, \\
& South Georgia, Heard Island, Macquarie Island \\
\hline
\end{tabular}

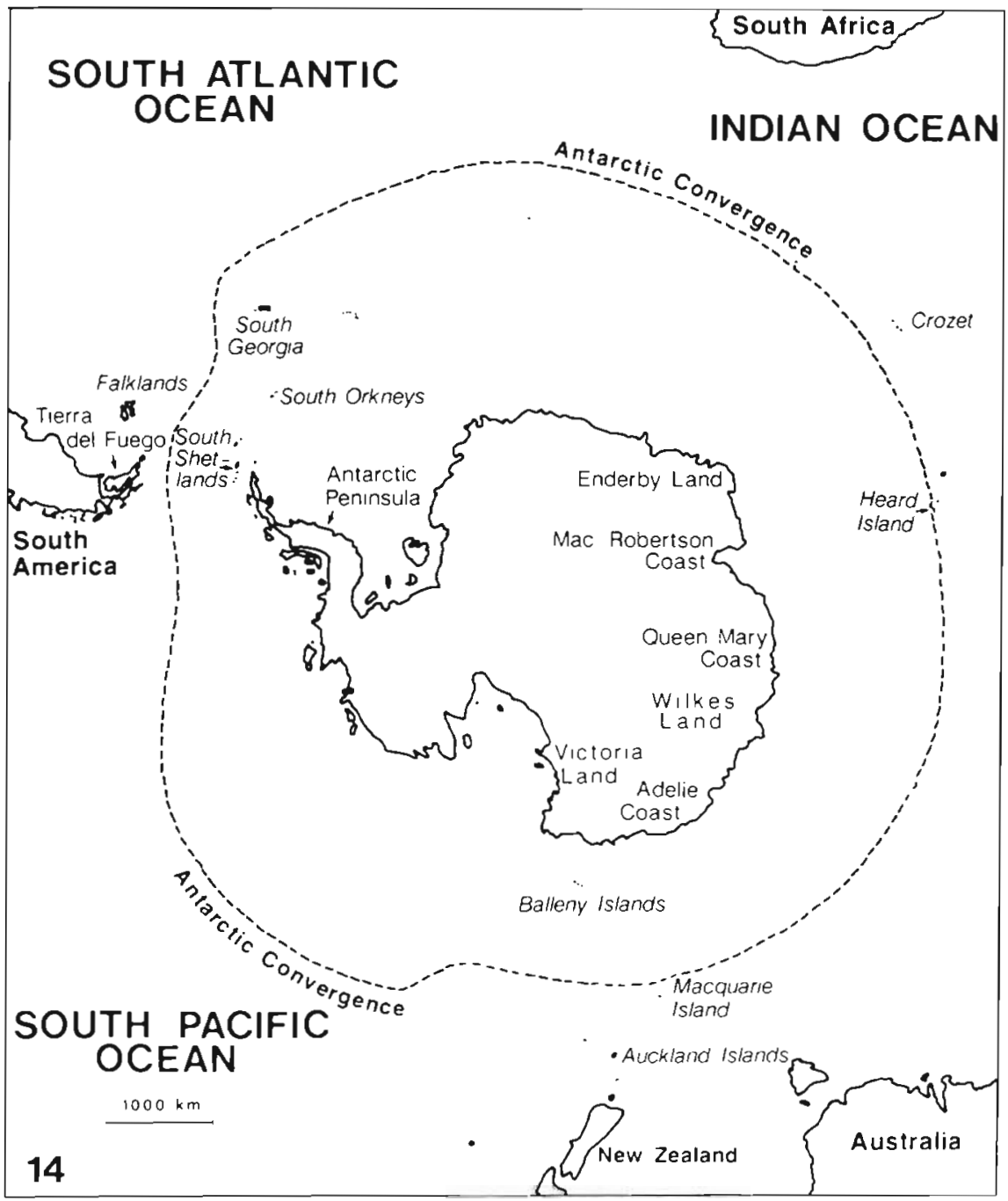

Fig. 14. Antarctica and its adjacent continents (redrawn after Stirling) 
Table 4. Variation of mean monthly seawater temperatures during the course of the year at various locations. Source: Gorshkov $(1985 a, b)$. Classification of biogeographic regions after Lüning (1985)

\begin{tabular}{|lc|}
\hline Location & Temperature $\left({ }^{\circ} \mathrm{C}\right)$ \\
\hline Antarctic Region: & \\
Antarctic Peninsula (east coast), Victoria Land, Adelie & the year \\
Coast, Wilkes Land, Queen Mary Coast, & $\leq-1.8$ to -0.2 \\
Mac Robertson Coast, Enderby Land & \\
Antarctic Peninsula (west coast, polar circle), & $\leq-1.8$ to +1.2 \\
Balleny Islands & $\leq-1.8$ to +1.4 \\
South Shetlands & -0.6 to +4.8 \\
South Orkneys & +1.5 to +5.2 \\
South Georgia & +5.0 to +8.0 \\
Heard Island & +4.2 to +8.5 \\
Cold-temperate (incl. Subantarctic) region: & +5.0 to +9.0 \\
Macquarie Island & +6.6 to +10.4 \\
Falklands & +8.0 to +11.0 \\
Crozet & +15.0 to +18.8 \\
Tierra del Fuego & \\
Auckland Islands & +15.5 to +20.0 \\
Victoria, South Australia & \\
Warm-temperate region: & \\
South Africa (Capetown) & \\
\hline
\end{tabular}

winter temperatures, allowing sufficient growth for the most temperature-sensitive phase in the life-cycle of a given alga. This is evident in Himantothallus grandifolius, found only in areas south of the Antarctic convergence with a temperature regime low enough $\left(<5^{\circ} \mathrm{C}\right)$ to permit growth of its sporophyte (Tables 3 and $4 ;$ Fig. 14). The maximum survival temperatures are considerably higher than the habitat temperatures and hence, do not limit the geographic distribution of any of the studied algae.

Sporophytes of Desmarestia anceps and Phaeurus antarcticus grow up to $5^{\circ} \mathrm{C}$ but are only found in waters characterized by a maximum mean monthly temperature of +1.2 to $+1.4{ }^{\circ} \mathrm{C}$ (Tables 3 and 4 ). If the known distribution is actually representative for the 2 species, the possibility that the temperature requirement for reproduction or incomplete dispersal limits their northern distribution has to be taken into account. A similar explanation is possible in Ascoseira mirabilis, which grows up to a temperature of $10^{\circ} \mathrm{C}$, but was not found in locations warmer than $4.8^{\circ} \mathrm{C}$ in August (Tables 3 and 4).

The geographic distribution of the investigated ligulate Desmarestia sp. is difficult to trace due to taxonomic and identification problems. It is now generally recognized that the members of this species group, which are distributed in cold and temperate waters of both hemispheres (Table 3), cannot be distinguished solely by vegetative characters (Anderson 1985, Peters \& Müller 1986, Ramirez et al. 1986). The populations of ligulate Desmarestia sp. north and south of the Antarctic convergence are probably not conspecific and differ e.g. in sporangium type (Moe \& Silva 1977, Anderson 1985, Wiencke unpubl.). The Antarctic entity cannot occur north of areas with winter temperatures much higher than $5^{\circ} \mathrm{C}$ as this would inhibit sporophytic growth (Fig. 11).

The distribution of Palmaria decipiens is limited by its temperature growth pattern. The alga grows at temperatures of up to $10^{\circ} \mathrm{C}$ (Fig. 14); the northernmost location of this species is Macquarie Island with mean monthly temperatures between 5 and $8^{\circ} \mathrm{C}$ (Tables 3 and 4 ; Fig. 14). This alga is the only species investigated in this study which occurs both in Antarctica and at a location north of the Antarctic convergence in the cold-temperate region.

On the organism level there is a high degree of adaptation to the low temperatures of the environment. What are the effects of temperature at the (sub)-cellular level and how are the high growth rates shown generated by cell metabolism? Enzymic reactions are strongly temperature dependent and hence, only low metabolic rates should be possible at low temperatures. This was demonstrated by Drew (1977) in HimantothalIus grandifolius, Desmarestia anceps and Palmaria decipiens. In these species the optimum temperature for photosynthesis is $15^{\circ} \mathrm{C}$, a temperature far above the ambient seawater temperatures in Antarctic waters and close to values for cold-temperate species (Lüning 1985). In Ascoseira mirabilis on the other hand a broad 
temperature optimum between 1 and $15^{\circ} \mathrm{C}$ was found for photosynthesis. This can be compared with results of Descolas-Gros \& de Billy (1987). They found maximum activity of RuBP carboxylase, the enzyme limiting photosynthetic rate, under light-saturating conditions at $4{ }^{\circ} \mathrm{C}$ in 3 Antarctic diatoms whereas temperate species showed a maximum activity at $20^{\circ} \mathrm{C}$.

This account exemplifies the need for more data on the physiology of Antarctic algae, whose growth is restricted to low temperatures.

Acknowledgements. The work was supported by a grant of the Deutsche Forschungsgemeinschaft to K. Lüning, Hamburg. The Instituto Antartico Chileno, Santiago de Chile, provided transport, accommodation and laboratory facilities in Antarctica. C. W. thanks M. Clayton, Melbourne, Australia, and R. Westermeier, Valdivia, Chile, for discussions and help during the field work. Cultures of Himantothallus grandifolius and Phaeurus antarcticus were gratefully obtained from $M$. Clayton. Technical assistance in maintaining cultures by $\mathrm{C}$. Langreder, Bremerhaven, and P. Kadel, Hamburg, is gratefully acknowledged. The figures were drawn by $\mathrm{K}$. Bremer and G. Dansauer, Bremerhaven. Finally, thanks to K. Lüning, Hamburg, for critically reading the manuscript.

\section{LITERATURE CITED}

Anderson, R. J. (1985). Morphological and taxonomic relationships among branched, ligulate members of the genus Desmarestia (Phaeophyceae, Desmarestiales), with particular reference to South African D. firma. Can. J. Bot. 63: 437-447

Biebl, R. (1958). Temperatur- und osmotische Resistenz von Meeresalgen der bretonischen Küste. Protoplasma 50: $217-242$

Biebl, R. (1962). Temperaturresistenz tropischer Meeresalgen. (Verglichen mit jener von Algen in temperierten Meeresgebieten.) Botanica mar. 4: 241-254

Biggs, W. W., Edison, A. G., Eastin, J. D., Brown, K. W. Maranville, W. J., Clegg, M. D. (1971). Photosynthesis light sensor and meter Ecology 52: 125-131

Bolton, J. J., Lüning, K. (1982). Optimal growth and maximal survival temperatures of atlantic Laminaria species (Phaeophyta) in culture. Mar. Biol. 66: 89-94

Clayton, M. N., Wiencke, C. (1986). Techniques and equipment for culturing Antarctic benthic marine algae, and for preparing specimens for electron microscopy. Ser cient. INACH 34: 93-97

Délépine, R., Asensi, A. (1976). Quelques données expérimentales sur l'ecophysiologie de Durvillea antarctica (Cham.) Hariot (Phéophycées). Bull. Soc. phycol. Fr 21. 65-80

Descolas-Gros, C., Billy de, G. (1987). Temperature adaptation of RuBP carboxylase: kinetic properties in marine Antarctic diatoms. J. exp. mar. Biol. Ecol. 108: 147-158

Drew, E. A. (1977). The physiology of photosynthesis and respiration in some Antarctic marine algae. Br Antarct. Surv. Bull. 46: 59-76

Fletcher, R. L. (1987). Seaweeds of the British Isles. Volume 3, Fucophyceae (Phaeophyceae) Part I. British Museum (Natural History), London

Gorshkov, S. G. (ed.) (1985a). World ocean atlas. Vol. 1. Pacific Ocean. Pergamon Press, Oxford

Gorshkov, S. G. (ed.) (1985b). World ocean atlas. Vol. 2 Atlantic and Indian Oceans. Pergamon Press, Oxford
Hempel, G. (1987). Die Polarmeere - ein biologischer Vergleich. Polarforschung 57: 173-189

Hoek, C., van den (1982a). The distribution of benthic marine algae in relation to the temperature regulation of their life histories. Biol. J. Linn. Soc. 18: 81-144

Hoek, C., van den (1982b). Phytogeographic distribution groups of benthic marine algae in the North Atlantic Ocean. A review from the experimental evidence from life histories. Helgoländer Meeresunters. 35: 153-214

Lamb, I. M. Zimmermann, M. H. (1977). Benthic marine algae of the Antarctic Peninsula. Antarctic Research Series, Vol. 23. Biology of the Antarctic Seas V, Paper V. Amer. Geophys. Union, Washington, D. C. p. 129-229

Lüning, K. (1984). Temperature tolerance and biogeography of seaweeds: the marine algal flora of Helgoland (North Sea) as an example. Helgoländer Meeresunters. 38: 305-317

Lüning, K. (1985). Meeresbotanik. Verbreitung, Ökophysiologie und Nutzung der marinen Makroalgen. Thieme Verlag, Stuttgart

Lüning, K., Guiry, M. D., Masuda, M. (1987). Upper temperature tolerance of North Atlantic and North Pacific geographical isolates of Chondrus species (Rhodophyta). Helgoländer Meeresunters. 41: 297-306

Moe, R. L., Silva, P. C. (1977). Sporangia in the brown algal genus Desmarestia with special reference to Antarctic $D$. ligulata. Bull. Jap. Soc. Phycol. 25: 159-167

Neushul, M. (1968). Benthic marine algae. Am. Geogr. Soc., New York, Antarctic Map Folio Series 10, p. 9-10, Plates 14. 15

Ohno, M. (1984). Culture of an Antarctic seaweed, Phyllophora antarctica (Phyllophoraceae, Rhodophyceae). In: Hoshiai, T., Fukuchi, M. (eds.) Proc of the 6th Symp. on Polar Biology. Nat. Inst. of Polar Research, Tokyo. Mem. natn. Inst. polar Res., Special issue 32: 112-116

Papenfuss, G. F. (1964). Catalogue and bibliography of Antarctic and subantarctic benthic marine algae. Am. Geophys. Union, Washington, D. C. Antarc. Res. Ser. 1: $1-76$

Peters, A. F., Müller, D. G. (1986). Life history studies - a new approach to the taxonomy of ligulate species of Desmarestia (Phaeophyceae) from the Pacific Coast of Canada. Can. J. Bot. 64: 2192-2196

Ramirez, M. E., Müller, D. G., Peters, A. F. (1986). Life history and taxonomy of two populations of ligulate Desmarestia (Phaeophyceae) from Chile. Can. J. Bot. 64: 2948-2954

Ricker, R. W. (1987). Taxonomy and biogeography of Macquarie Island seaweeds. British Museum (Natural History). London

Rueness, J., Tanager, T. (1984). Growth in culture of four red algae from Norway with potential for mariculture. Hydrobiologia 116/117: 303-307

Seagrief, S. C. (1984). A catalogue of South African green, brown and red marine algae. Mem. Bot. Surv. South Africa 47: $1-72$

Simons, R. H. (1976). Seaweeds of Southern Africa: guidelines for their study and identification. Fish Bull. S. Afr. 7: 1-113

Stein, J. R. (1973). Handbook of phycological methods. Culture methods and growth measurements. Cambridge University Press, Cambridge

Stirling, I. F. Antarctic regions and continents. Dept. of Lands and Survey N. Z., Wellington, New Zealand

Wiencke, C. (1988). Notes on the development of some benthic marine macroalgae of King George Island, Antarctica. Ser. cient. INACH 37: 23-47

Womersley, H. B. S. (1987). The marine benthic flora of Southern Australia, Part II. South Australia Government Printing Division, Adelaide 
Zaneveld, J. S. (1966). The occurrence of benthic marine algae under shore fast-ice in the western Ross Sea, Antarctica. Proc. Int. Seaweed Symp. 5: 217-231

This article was submitted to the editor
Zaneveld, J. S. (1968). Benthic marine algae, Ross Island to Balleny Islands. Am. Geogr. Soc., New York. Antarctic Map Folio Series, Folio 10: 1-12

Manuscript first received: December 2, 1988 Revised version accepted: March 23, 1989 